\title{
A Systematic Plan for Firearms Law Reform
}

\author{
Katherine L. Record \\ Georgetown University Law Center, klr9@law.georgetown.edu \\ Lawrence O. Gostin \\ Georgetown University Law Center, gostin@law.georgetown.edu
}

Georgetown Public Law and Legal Theory Research Paper No. 13-014

This paper can be downloaded free of charge from:

https://scholarship.law.georgetown.edu/facpub/1182

http://ssrn.com/abstract=2224156

\section{Katherine L. Record, Lawrence O. Gostin, A Systematic Plan for Firearms Law Reform, JAMA Online (February 7, 2013), http://jama.jamanetwork.com/article.aspx?articleid=1569362}

This open-access article is brought to you by the Georgetown Law Library. Posted with permission of the author. Follow this and additional works at: https://scholarship.law.georgetown.edu/facpub 


\section{A Systematic Plan for Firearms Law Reform}

Katherine L. Record, JD, MPH, MA

Lawrence O. Gostin, JD

$\mathrm{T}$ Hat WAS THE WORST DAY OF MY PRESIDENCy. SOMEthing fundamental in America has to change," remarked President Obama, digesting the tragic massacre of 20 grade-school children in Newtown, Connecticut. ${ }^{1}$ The United States has nearly as many firearms as inhabitants; while mortality rates from most major causes of injury have significantly declined, the number of annual firearms fatalities (32163 in 2011) has not decreased. ${ }^{2}$ Even the political discussion in the wake of Newtown resulted in a spike in firearm sales. President Obama's plan to reduce firearm violence includes (1) closing background check loopholes; (2) banning assault weapons and high-capacity magazines; and (3) improving mental health services. ${ }^{3}$

The right to bear arms has never been more robust than at the turn of the century, with the expiration of a federal assault weapons ban, the Supreme Court reading the Second Amendment's "militia" to refer to civilians for the first time in history, and states relaxing concealed weapon laws. Although the president's plan is well within the confines of the Constitution, the limits imposed by the Court, combined with a fragmented mental health system, mean that no constitutionally permissible plan will be fully effective. Still, the president's plan could reduce the devastating toll of firearm injuries and deaths through a public health strategy.

\section{Closing Background Check Loopholes}

The Gun Control Act of 1968 restricts "prohibited persons" from purchasing firearms, including individuals who are felons, subject to restraining orders, addicted to controlled substances, involuntarily committed, or adjudicated incompetent or dangerous. Licensed firearms dealers must conduct background checks using the National Instant Criminal Background Check System (NICS).

However, prohibited persons can easily avoid background checks by purchasing from unlicensed (secondhand) dealers, who frequent gun shows. Moreover, 19 states issue "Brady permits" allowing licensed sellers to waive back-

See related article. ground checks; 7 such states do not exclude mentally ill individuals from purchasing firearms. ${ }^{4}$ The president proposes requiring all sellers (Internet, private, gun show) to run a buyer's name through the NICS database, thereby making it more difficult for dangerous individuals to obtain firearms. Just as it is constitutional to require licensed dealers to run these checks, this proposal does not violate the right to bear arms.

The president's proposal is necessary but insufficient in that it contains no enforcement mechanism and fails to prohibit individuals from buying a multitude of weaponry, as occurred with the Newtown perpetrator's mother. Background check enforcement is nearly nonexistent; in 2010, 80000 Americans were caught falsifying a firearm application, but only 44 were prosecuted. ${ }^{3}$

Beyond loopholes, the verification system is inaccurate and incomplete, with many prohibited persons never entered into the NICS database. The Court has ruled that Congress cannot compel states to report prohibited persons. Consequently, some states overreport (eg, mental health outpatients), whereas others underreport (eg, only individuals committed for 90 days or to public hospitals). Moreover, as of 2007, 28 states did not report inpatients with mental illness, and 17 have reported fewer than 10 mental health records since the database's creation. ${ }^{3}$ The Government Accountability Office estimates that NICS's mental illness data fall short by 2 million individuals. ${ }^{5}$ The Obama administration wants to invest $\$ 20$ million to incentivize states to report, but states with the greatest firearms trade may choose not to comply.

\section{Banning Assault Weapons and High-Capacity Magazines}

The president's plan to ban the sale of military-style assault weapons, high-capacity magazines, and armor-piercing bullets (which threaten law enforcement officers) would likely pass Second Amendment scrutiny, although the Court has not detailed the extent to which Congress can control the possession and trade of arms. Semiautomatic weapons and large magazine clips are not necessary for

Author Affiliations: Center for Health Law \& Policy Innovation, Harvard Law School, Boston, Massachusetts (Ms Record); and O'Neill Institute for National and Global Health Law, Georgetown University, Washington, DC (Mr Gostin).

Corresponding Author: Lawrence O. Gostin, JD, Georgetown University Law Center, 600 New Jersey Ave NW, Washington, DC 20001 (gostin@law.georgetown .edu). 
any legitimate purpose-whether hunting, self-defense, or sport. These weapons were used in the mass shootings in Newtown, Virginia Tech, Tucson, and Aurora.

A 2003 report suggested that states that restrict these and other weapons have the lowest per capita homicide rates. ${ }^{6}$ Yet individuals already own millions of assault weapons; the federal ban does not include a plan to confiscate them. Furthermore, no state alone can rectify the problem because firearms are nearly ubiquitous in interstate and international commerce-fueled by the illicit drug trade. Firearm control is one area in which federal rules clearly are necessary.

\section{Improving Mental Health Services}

Perpetrators of mass violence are often mentally ill but have gained access to semiautomatic arms. The president seeks resources to train teachers, health care professionals, and social workers to identify mental illness and facilitate interaction among school, law enforcement, and mental health agencies-focusing particularly on adolescents. The administration has launched a national dialogue with the aim of reducing the stigma of seeking mental health care. The Affordable Care Act requires health plans in the small and individual market, as well as Medicaid, to afford parity to mental health services. Yet this does not apply to most large employer-sponsored plans, and the scope of mental health benefits has yet to be defined.

\section{A Fundamental Change}

No set of proposals can eliminate the public health threat of firearms-whether through inner-city violence, mass murders, suicides, or inadvertent firearm discharges. Yet sensible firearm restrictions can reduce violence. Countries such as Australia and the United Kingdom intensified gun controls following mass murders, drastically reducing firearm injuries and deaths to levels a fraction of those in the United States.

Firearm violence is vividly depicted, often glorified, in television, films, and video games. Impressionable children and adolescents are not only exposed to these images but are actively courted through competitions. There are insufficient data to know whether these depictions are causally related to gun violence, although the president would like to promote research. However, constraining the media faces formidable political and constitutional challenges-as the media (like the firearms industry) is a powerful lobby and is afforded robust First Amendment protection.

The public supports reasonable firearm restrictions, which also appear to be constitutionally permissible. Yet legisla- tors for years have blocked most gun safety legislation, such as mandatory trigger locks, fingerprint technology (so only the lawful owner can discharge a weapon), training requirements, and limits on mass sales. President Obama's proposals do not even touch on these public health strategies.

Legislators have also made it extraordinarily difficult for law enforcement by limiting the exchange of information or permitting "tracking and tracing" for firearms and ammunition. Consequently, federal, state, and city officials lack the basic tools needed to detect, prevent, and punish firearmrelated crime. The Senate has failed to consent to any nomination to lead the federal agency charged with overseeing firearms. Congress has even impeded studies into the causes of and remedies for firearm violence-effectively freezing Centers for Disease Control and Prevention research and banning federal funding "to advocate or promote gun control." 3

In the aftermath of Newtown, legislators have made clear that they will oppose any regulation that impedes the "grandfather-to-grandson exchange [of arms] ... that takes place under the Christmas tree every year." The endemic gun violence in inner cities across the countrywhich causes trepidation, death, and imprisonment among impoverished adolescents-has not captured political attention. Whether a massacre of grade-school children in a Connecticut town will alter the political dynamics remains unclear. The nation can only hope that the worst tragedies will inspire the greatest bipartisan courage.

Published Online: February 7, 2013. doi:10.1001/jama.2013.1127 Conflict of Interest Disclosures: Both authors have completed and submitted the ICMJE Form for Disclosure of Potential Conflicts of Interest and none were reported.

\section{REFERENCES}

1. Obama B. Meet the Press [transcript]. NBC television. December 30, 2012. 2. Hoyert DL, Jiaquan X. Deaths: Preliminary Data for 2011: Selected Causes, National Vital Statistics Reports. Hyattsville, MD: Dept of Health and Human Services; 2012.

3. White House. Now is the time: the President's plan to protect our children and our communities by reducing gun violence. January 16, 2013. http://www .whitehouse.gov/sites/default/files/docs/wh_now_is_the_time_full.pdf. Accessed February 1, 2013.

4. Bureau of Alcohol, Tobacco, Firearms, and Explosives. State Laws and Published Ordinances: Firearms. 29th ed. Washington, DC: Bureau of Alcohol, Tobacco, Firearms and Explosives; 2008:i-480.

5. US General Accounting Office. Gun Control: Options for Improving the National Instant Criminal Background Check System. April 2000. http://www.gao .gov/archive/2000/gg00056.pdf. Accessed February 1, 2013.

6. Wiebe DJ. Homicide and suicide risks associated with firearms in the home: a national case-control study. Ann Emerg Med. 2003;41(6):771-782.

7. Steinhauer J. Closing gun-sale loophole rises on agenda. New York Times. January 19, 2013. http://www.nytimes.com/2013/01/20/us/politics/other -proposals-taking-precedence-in-congress-over-gun-ban.html?_r=0. Accessed February 5, 2013. 